University of Nebraska - Lincoln

DigitalCommons@University of Nebraska - Lincoln

Faculty Papers and Publications in Animal

Science

Animal Science Department

10-12-1989

\title{
CONTROL OF LUTEINIZING HORMONE IN POSTPUBERTAL BOARS WITH LARGE TESTES
}

\author{
P. L. Wolfe \\ University of Nebraska-Lincoln \\ M. W. Wolfe \\ University of Nebraska-Lincoln, mwolfe2@kumc.edu \\ T. T. Stumpf \\ University of Nebraska-Lincoln \\ J. A. Stotts \\ University of Nebraska-Lincoln \\ M. L. Day \\ University of Nebraska-Lincoln \\ See next page for additional authors
}

Follow this and additional works at: https://digitalcommons.unl.edu/animalscifacpub

Part of the Animal Sciences Commons

Wolfe, P. L.; Wolfe, M. W.; Stumpf, T. T.; Stotts, J. A.; Day, M. L.; Kittock, R. J.; Johnson, R. K.; and Kinder, J. E., "CONTROL OF LUTEINIZING HORMONE IN POSTPUBERTAL BOARS WITH LARGE TESTES" (1989). Faculty Papers and Publications in Animal Science. 48.

https://digitalcommons.unl.edu/animalscifacpub/48

This Article is brought to you for free and open access by the Animal Science Department at DigitalCommons@University of Nebraska - Lincoln. It has been accepted for inclusion in Faculty Papers and Publications in Animal Science by an authorized administrator of DigitalCommons@University of Nebraska - Lincoln. 


\section{Authors}

P. L. Wolfe, M. W. Wolfe, T. T. Stumpf, J. A. Stotts, M. L. Day, R. J. Kittock, R. K. Johnson, and J. E. Kinder 


\title{
CONTROL OF LUTEINIZING HORMONE IN POSTPUBERTAL BOARS WITH LARGE TESTES 1
}

\author{
P. L. Wolfe, M. W. Wolfe, T. T. Stumpf, \\ J. A. Stotts ${ }^{2}$, M. L. Day ${ }^{3}$ R. J. Kittok, \\ R. K. Johnson and J. E. Kinder ${ }^{4}$ \\ University of Nebraska ${ }^{5}$ \\ Lincoln, NE 68583-0908
}

\begin{abstract}
The objective of the present study was to investigate endocrine control of LH in postpubertal boars with large testes. Eight boars with the highest estimated paired testis weights from a line selected for large testes and nine boars from a line selected at random were used. Blood samples were collected over a 13-h period at weekly intervals for $4 \mathrm{wk}$. Samples were collected at 12-min intervals for $12 \mathrm{~h}$ before and $1 \mathrm{~h}$ after exogenous LHRH. Boars were bled when they were intact during the initial week. The second and third blood collections were 7 and $14 \mathrm{~d}$ after castration. The fourth bleeding occurred $7 \mathrm{~d}$ after exogenous $17 \beta$-estradiol $\left(E_{2}\right)$ replacement. In intact boars, mean LH was similar between boars from the two groups, but amplitude of pulses of LH was lower in intact boars with large testes than in boars from the control line. Maximum concentration of LH after administration of LHRH was less in boars with large testes than in boars from the control group. Seven days after castration, characteristics of $\mathrm{LH}$ measured did not differ between males from the two groups. However, $14 \mathrm{~d}$ after castration, amplitude of pulses of LH and maximum concentrations of $\mathrm{LH}$ after LHRH were less in males from the group with large testes than in males from the control group. After $E_{2}$ administration, amplitude of pulses of $\mathrm{LH}$ tended to be lower in males from the group with large testes than in males from the control group. Therefore, amplitude of pulses of LH and responsiveness of the anterior pituitary to LHRH are suppressed in porcine males with larger testes compared with males from a control group both before and after castration.
\end{abstract}

(Key Words: Boars, Testes, LH, Testosterone, Estradiol.)

J. Anim. Sci, 1989. 67:1334-1340

\section{Introduction}

Relative to concentrations of $\mathrm{LH}$ in intact boars, concentrations of $\mathrm{LH}$ were elevated in prepubertal (Colenbrander et al., 1977) and adult (FlorCruz and Lapwood, 1978) porcine males within 2 to 4 wk after castration. Mean concentrations of $\mathrm{LH}$ also increased following castration of 14-wk-old boars (Kittok et al., 1984b). Kittok et al. (1984a) reported that concentrations of $\mathrm{LH}$ were greater in boars (15 wk of age) without an implant containing 17 $\beta$-estradiol $\left(\mathbf{E}_{2}\right)$ than in boars receiving $\mathbf{E}_{2}$. There were no differences in plasma concentrations of LH in rams selected for either high or low weight of the testes (McNeilly et al., 1986). Schinckel et al. (1984) reported that boars selected for large testes had higher concentrations of LH from 42 through $140 \mathrm{~d}$ of 
age than boars selected for smaller testes. A positive genetic relationship between size of testes in males and ovulation rate in daughters has been found in mice (Land, 1973; Mafizul Islam et al., 1976; Joakimsen and Baker, 1977), sheep (Carr and Land, 1975; Hanrahan and Quirke, 1977) and swine (Schinckel et al., 1984). This relationship exists because the same gonadotropins that control development of testes in males have parallel roles in controlling ovarian function in females (Land, 1973). Because increased size of testes may alter endocrine function, the objective of the present study was to determine whether postpubertal boars with large testes had an endocrine control of $\mathrm{LH}$ different from that of boars with smaller testes.

\section{Materials and Methods}

Seventeen sexually mature (14 to 15 mo of age) Large White $x$ Landrace boars were used in the study. Eight boars were from a line selected for larger testes at $150 \mathrm{~d}$ of age as described by Schnickel et al. (1984); nine boars were from a control line in which no selection pressure for size of the testes had been applied. The eight boars from the selection line represented the second generation of selection for larger testes of an ongoing selection experiment at the University of Nebraska. The eight boars used of the study were the sires for the next generation of the selection line and therefore were the boars with the largest testes in that generation.

Boars were weighed, tethered in stalls assigned randomly and fitted with indwelling jugular catheters via ear vein cannulation techniques as described by Kelly (1986). All boars were adapted to tethering and manipulations required during blood collection during the 2 wk preceding the experiment. Boars were maintained in an environmentally controlled room at a constant temperature and exposed to continuous lighting. All boars were fed $1.8 \mathrm{~kg}$ of a diet containing corn and soybean meal (14\% protein) each day and had access to water ad libitum.

Blood samples were collected over a 13-h period at weekly intervals for 4 wk. At each period, blood was collected at 12-min intervals for $12 \mathrm{~h}$, after which an exogenous dose of

\footnotetext{
${ }^{6}$ Elanco Products Co., Indianapolis, IN.
}

LHRH was administered i.v. (188 $\mathrm{ng} / \mathrm{kg} \mathrm{BW}$ ) and blood samples were collected for an additional hour. Blood samples were collected from intact boars during the initial period of blood collection. After this period of blood collection, all boars were anesthetized with sodium thiamylal and castrated. Excised tissues were wrapped in plastic until weights were determined ( 30 to 40 min later). Trimmed paired testes and epididymal weights were recorded for each animal. The second and third periods of blood collection were 7 and $14 \mathrm{~d}$ after castration. At the conclusion of the third period of blood collection, implants containing $\mathrm{E}_{2}$, Compudose ${ }^{6}$, were administered subcutaneously at the ventral midline to each animal (.528 $\mathrm{mg} \mathrm{E} \mathrm{E}_{2} / \mathrm{kg} \mathrm{BW}$ ). Thus, the fourth period of blood collection was $7 \mathrm{~d}$ after implantation of $\mathrm{E}_{2}$.

Radioimmunoassays. Each blood sample $(5.0 \mathrm{ml})$ was mixed with $60 \mu \mathrm{l}$ of $15 \%$ EDTA dipotassium salt. Samples then were stored at $4^{\circ} \mathrm{C}(6$ to $12 \mathrm{~h})$ until centrifugation at $3,500 \times$ $g$ for $30 \mathrm{~min}$. The plasma fraction was decanted and stored at $-20^{\circ} \mathrm{C}$. All plasma samples were analyzed for concentrations of LH; pooled samples (within boar) from each day of blood collection were used to quantify concentrations of $E_{2}$ and testosterone. Samples collected subsequent to administration of LHRH were not included in the pools.

Concentrations of $\mathrm{LH}$ were determined in duplicate $300-\mu \mathrm{l}$ aliquots of plasma by a double antibody radioimmunoassay described by Niswender et al. (1970). Purified LH (LER786-3) was used as a standard and for iodination, and anti-porcine LH (no. 566) was utilized as the first antibody. Recovery of added mass $(78,156$ and $312.5 \mathrm{pg}$ of porcine LH, LER-786-3) from each of four plasma samples averaged $115.8 \pm 3.5 \%$. Assay determinations of 200,250 and $300 \mu \mathrm{l}$ of plasma from each of 10 independent samples were highly correlated ( 200 and $250 \mu \mathrm{l}, \mathrm{r}=.989$; 200 and $300 \mu l, r=.935$; and 250 and $300 \mu l$, $r=.937)$. Intra- and inter-assay coefficients of variation were $2.7 \%$ and $11.9 \%$, respectively. Assay sensitivity was $49 \mathrm{pg} / \mathrm{ml}$ plasma.

Plasma concentrations of $E_{2}$ were determined using methods described by D'Occhio et al. (1982) and validated in our laboratory (Kittok et al., 1984b). Intra- and inter-assay coefficients of variation were $2.7 \%$ and $10.3 \%$, respectively. Assay sensitivity was $1.4 \mathrm{pg} / \mathrm{ml}$ plasma. 
TABLE 1. BODY WEIGHT, EXCISED TESTES WEIGHTS AND EXCISED EPIDIDYMIDES WEIGHTS IN BOARS WITH LARGER TESTES AND BOARS FROM A CONTROL GROUP

\begin{tabular}{lccc}
\hline & & $\begin{array}{l}\text { Excised paired } \\
\text { testis wt, g }\end{array}$ & $\begin{array}{l}\text { Excised paired } \\
\text { epididymides wt, g }\end{array}$ \\
\hline Large testes & $\mathrm{BW}, \mathrm{kg}$ & $868^{\mathrm{b}}$ & 216 \\
Control & 183 & $689^{\mathrm{c}}$ & 191 \\
SE & 182 & 24 & 14 \\
\hline
\end{tabular}

"Boars were castrated and testes weights were determined when boars were 14 to 15 mo of age.

${ }^{b, c}$ Means with unlike superscripts in same column differ $(P<.05)$.

Plasma concentrations of testosterone were determined using methods similar to those described by Kiser et al. (1978). Procedural loss was assessed by recovery of labeled testosterone and assay determinations were corrected for that loss. Recovery of added mass (31.3, 62.5 and $125 \mathrm{pg}$ testosterone) from $5 \mu \mathrm{l}$ of plasma from each of six independent samples averaged $109.1 \pm 4.1 \%$. Assay determinations of $5,5.5$ and $6 \mu \mathrm{l}$ of sample from each of 12 independent samples were highly correlated ( 5 and $5.5 \mu \mathrm{l}, \mathrm{r}=.994 ; 5$ and $6 \mu \mathrm{l}, \mathrm{r}$ $=.997$; and 5.5 and $6 \mu \mathrm{l}, \mathrm{r}=.996$ ). Intra- and inter-assay coefficients of variation were $2.7 \%$ and $7.7 \%$, respectively. Assay sensitivity was $49.4 \mathrm{pg} / \mathrm{ml}$ plasma.

Data Analyses. Characteristics of LH evaluated were mean concentratuon of $\mathrm{LH}$ in plasma, frequency of pulses of $\mathrm{LH}$, amplitude of pulses of $\mathrm{LH}$, concentrations of $\mathrm{LH}$ in circulation subsequent to administration of exogenous LHRH and minutes from time of administration of LHRH to time that maximum concentrations of LH were detected. Mean plasma concentration of $\mathrm{LH}$ for an individual was the average concentration detected in the 60 samples collected during a period of blood collection. Frequency of pulses of LH was expressed as number of pulses detected per hour during each of four 12-h collection periods; amplitude of pulses of $\mathrm{LH}$ was expressed as the average amplitude of all pulses detected during any given $12-\mathrm{h}$ period of blood collection. Pulses of LH were identified and amplitudes of pulses in LH were calculated using methods described by Goodman and Karsch (1980).

Statistical Analyses. Data in this experiment were analyzed initially to determine whether the variance-covariance matrix for the four treatments was heterogeneous (Gill and Hafs, 1971). If heterogeneity was found in the variance-covariance matrix, the data were transformed (logarithmic) and retested. After the variance-covariance matrix was determined to be homogenous (original or transformed data), the data were analyzed according to the procedures of Gill (1986) for experiments with repeated measures. Determinations of mean concentrations of $\mathrm{LH}$ from samples before and after administration of LHRH were analyzed separately. In each case, data for mean LH concentrations were fitted to a model that included effects of group (large testes or control), boars within groups, treatment (intact, $7 \mathrm{~d}$ post-castration, $14 \mathrm{~d}$ post-castration, and implanted with $E_{2}$ ) and group $\times$ treatment. Measures of $E_{2}$, testosterone, data for frequency and amplitude of pulses of LH and measures of LH in response to LHRH also were fitted to a model that included effects of group, treatment and group $\times$ treatment. Least squares means were calculated for each characteristic in males with the large testes and males from control groups. Comparisons of treatment means were made using orthogonal contrasts and Student's $t$-test (Harvey, 1979), and SE of these contrasts were calculated as described by Gill (1986).

\section{Results}

Boars from both groups had similar BW. Boars from the group selected for larger testes at $150 \mathrm{~d}$ of age had heavier $(P<.05)$ testis weights when castrated at 14 mo of age (Table 1). Epididymal weights were not significantly different between boars within the two groups.

In intact boars, mean concentrations of $\mathrm{LH}$ were similar between boars with the larger testes and boars from the control group (Figure 1). Seven days after castration, mean concentrations of LH in castrates of both groups were greater $(P<.05)$ than concentrations of LH in the plasma collected 1 wk earlier when the boars were intact. On 7 and $14 \mathrm{~d}$ after 


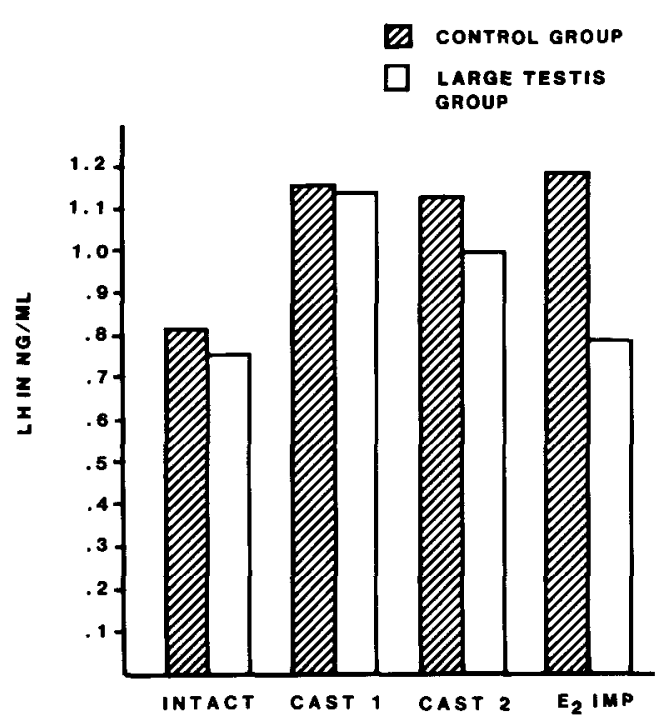

Figure 1. Mean concentrations of LH in blood plasma of intact porcine males with large testes and males from a control group. Concentrations of LH in these males 7 (Cast 1) and $14 \mathrm{~d}$ (Cast 2) following castration and $7 \mathrm{~d}$ subsequent to implantation with $E_{2}\left(21 \mathrm{~d}\right.$ postcastration; $E_{2} I \mathrm{mp}$ ) also are shown. None of the differences between boars in the two groups were significant $(P>.10)$.

castration, mean concentrations of LH were similar between animals of both groups.

In intact boars, amplitude of pulses of $\mathrm{LH}$ was lower $(P<.05)$ in boars with larger testes than in boars from the control group (Figure 2). Seven days following castration, amplitude of pulses of LH was not significantly different between males in the two groups, but $14 \mathrm{~d}$ after castration, amplitude of pulses of $\mathrm{LH}$ tended to be lower $(P<.10)$ in males from the group with larger testes prior to castration. Following $\mathrm{E}_{2}$ replacement, amplitude of pulses of $\mathrm{LH}$ also tended $(P<.10)$ to be lower in males that had larger testes before castration than in males from the control group. Castration increased $(P<.01)$ amplitude of pulses of LH. Implantation with $\mathrm{E}_{2}$ returned amplitude of pulses of $\mathrm{LH}$ to values that were not different $(P>.10)$ from those detected in intact males.

Frequency of pulses at each period of blood collection was not significantly different between males of the two groups (Figure 3). Castration increased $(P<.01)$ frequency of pulses of $\mathrm{LH}$. Implantation with $\mathrm{E}_{2}$ resulted in a return of frequency of pulses to a frequency

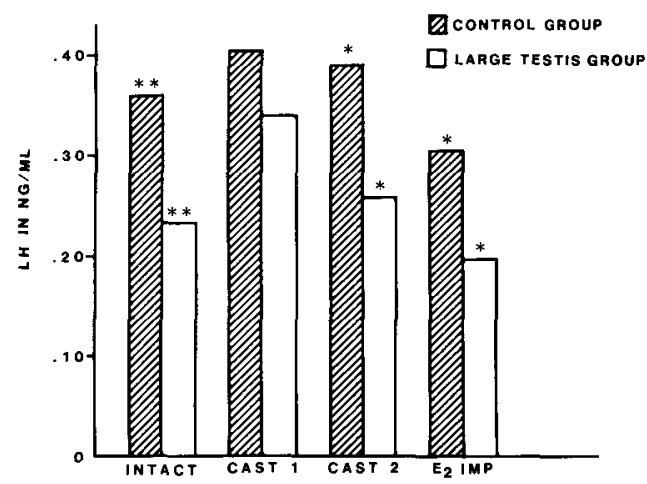

Figure 2. Amplitude of pulses of $\mathrm{LH}(\mathrm{ng} / \mathrm{ml}$ blood plasma) in intact porcine males with large testes and males from a control group. Amplitude of pulses of $\mathrm{LH}$ in these males 7 (Cast 1 ) and $14 \mathrm{~d}$ (Cast 2) following castration and 7 $d$ subsequent to implantation with $E_{2}\left(21 \mathrm{~d}\right.$ postcastration; $E_{2}$ Imp) also are shown. Values within treatment period with two stars or one star differ $(P<.05 ; P<.10$, respectively).

similar to that detected in intact males $(P>$ $.10)$.

Testosterone in pooled samples was not significantly different in intact boars of both groups $(6.9$ and $5.9 \mathrm{ng} / \mathrm{ml}$ plasma in boars with larger testes and control boars, respectively). Estradiol in plasma was not significantly different between boars of the two groups (169 and $119 \mathrm{pg} / \mathrm{ml}$ of plasma in boars with larger testes and control boars, respectively). After replacement of $E_{2}$, concentrations of $E_{2}$ in plasma were similar for males in both groups (92 $\mathrm{pg} / \mathrm{ml}$ plasma in males with larger testes before castration compared with $114 \mathrm{pg} / \mathrm{ml}$ in males of control group).

Maximum concentrations of $\mathrm{LH}$ after administration of LHRH were lower $(P<.05)$ in boars with larger testes than in intact boars from the control group (Figure 4). Maximum release of LH after exogenous LHRH was not different between males of the two groups $7 \mathrm{~d}$ after castration. However, 2 wk after castration, maximum release of $\mathrm{LH}$ in response to LHRH was lower $(P<.05)$ in males from the group that had larger testes before the time of castration. Following $E_{2}$ replacement, response to LHRH was not significantly different for males in the two groups.

Duration of time between administration of LHRH and subsequent peak concentrations of LH was similar in males of both groups during every blood collection period except at $7 \mathrm{~d}$ after castration. At this time, males from the 


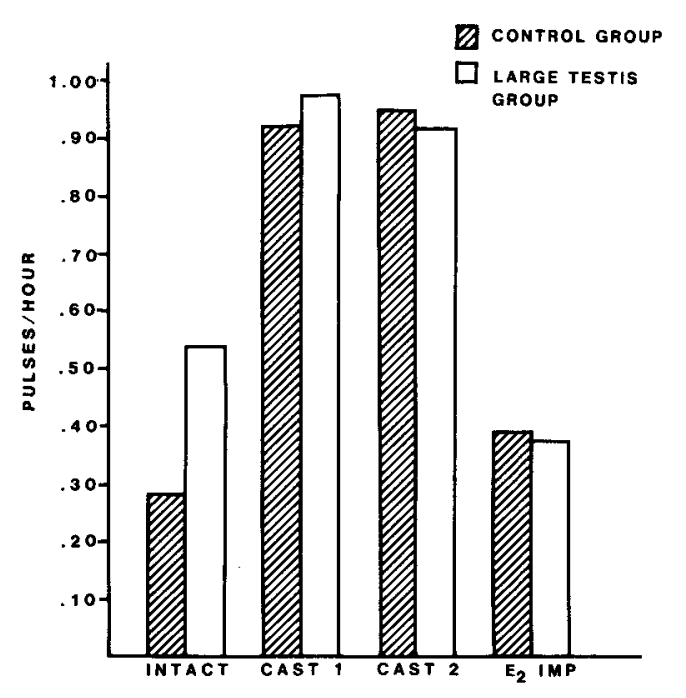

Figure 3. Frequency of pulses of $\mathbf{L H}$ in intact porcine males with large testes and males from a control group. Frequency of pulses of LH in these males 7 (Cast 1) and $14 \mathrm{~d}$ (Cast 2) following castration and $7 \mathrm{~d}$ subsequent to implantation with $E_{2}\left(21 \mathrm{~d}\right.$ postcastration; $E_{2}$ Imp) also are shown. None of the differences between boars in the two groups were significant $(P>.10)$.

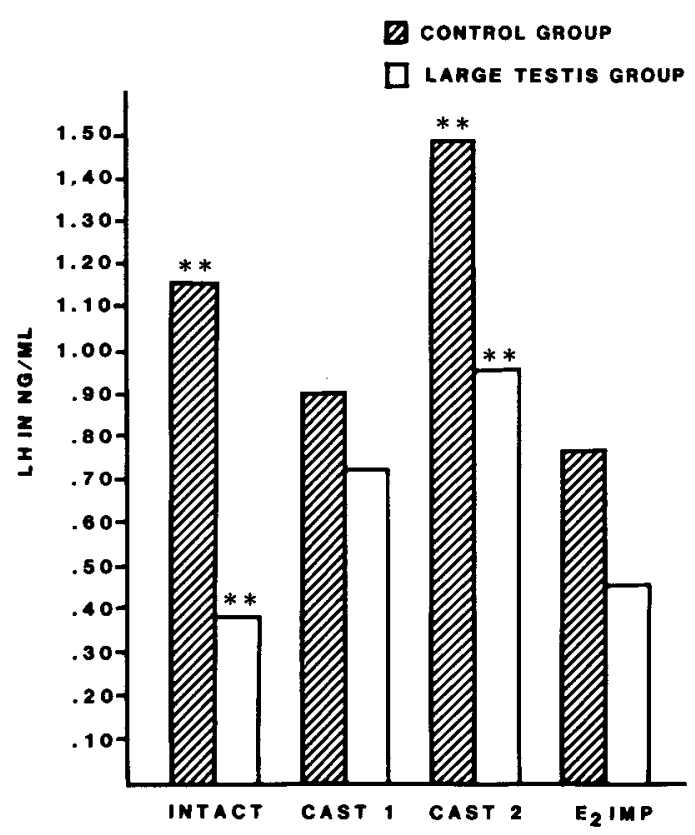

Figure 4. Maximum concentration of $\mathbf{L H}$ after administration of LHRH in porcine males with large testes and males from a control group. Maximum concentrations of $\mathrm{LH}$ after LHRH in these males 7 (Cast 1) and 14 (Cast 2) d after castration and $7 \mathrm{~d}$ subsequent to implantation with $\mathrm{E}_{2}(21 \mathrm{~d}$ postcastration; $\left.E_{2} I m p\right)$ also are shown. Values with two stars within treatment period differ $(P<.05)$. group that had larger testes before castration took longer to reach their maximum concentration of LH after administration of LHRH than males to the control group (22.5 vs $13.3 \mathrm{~min}$; $P<.05$ ).

\section{Discussion}

The observed difference in size of the testes between boars of the two groups in the present study was independent of $\mathrm{BW}$ because $\mathrm{BW}$ were not different between boars of the two groups. As expected, castration resulted in greater mean concentrations of $\mathrm{LH}$ and an increase in frequency and amplitude of pulses of $\mathrm{LH}$ when boars of both groups were combined. Thus, control of secretion of $\mathrm{LH}$ in adult boars is modulated by negative feedback of testicular steroids, as observed in prepubertal boars by Kittok et al. (1984b). In the present study, implantation with $E_{2}$ returned characteristics of secretion of LH to precastration values. Thus, $\mathrm{E}_{2}$ apparently is a major factor in modulation of secretion of $\mathrm{LH}$ in the mature boar. This is in agreement with the results reported by Kittok et al. (1984a) for prepubertal boars.

The most interesting finding in the present study was the decreased amplitude of pulses of LH in boars from the group with larger testes. This could not be attributed to differences in gonadal steroid feedback because differences in amplitude of pulses between males within the two groups also were detected subsequent to castration. Similar differences in amplitude of pulses of LH were detected when exogenous $\mathrm{E}_{2}$ was administered. This decreased amplitude of pulses in LH could result from decreased responsiveness of the pituitary to LHRH and(or) from decreased amplitude of pulses of LHRH released from the hypothalamus. We detected a decreased responsiveness of the pituitary gland with regard to maximum concentration of $\mathrm{LH}$ released after exogenous LHRH administration. Therefore, the most likely reason for decreased amplitude of pulses in LH in boars with larger testes is a decreased responsiveness of the anterior pituitary gland to LHRH. Why this would occur in boars with larger testes cannot be explained at present. We would have expected an increased responsiveness of the pituitary gland to LHRH in animals with the larger testes if a difference in this characteristic were to exist between boars of the two groups. Therefore, this finding was 
unexpected and does not help us explain the endocrine factors involved in variation of gonadal size between boars.

In intact and castrated males, plasma concentrations of LH and frequency of pulses of LH were not different. These results are not consistent with the results of Schinckel et al. (1984) in that prepubertal boars selected for larger testes had higher concentrations of $\mathrm{LH}$ than boars selected for smaller testes. One explanation for the inconsistent results may be that no selection pressure was applied to boars of the control group in the present study, whereas the prepubertal boars in one group in the previous study were selected for smaller testes. Therefore, reductions in concentrations of LH may have resulted from selection for smaller testes. However, the most likely reason for the inconsistent results between the two studies relates to differences in stage of sexual maturation and the influence of maturation on secretion of $\mathrm{LH}$.

Concentrations of testosterone and $E_{2}$ were similar between the intact boars of the two groups. This finding is not in agreement with data from prepubertal boars selected for larger testes that indicated that prepubertal boars consistently had greater concentrations of $E_{2}$ than their contemporaries selected for smaller testes (Schinckel et al., 1984). Reasons for the differences in the data from the two studies may be related to age. Selection for larger testes may change endocrine function so that the hypothalamo-pituitary axis of males in the selection group is less sensitive to suppressive effects of gonadal steroids (Schinckel et al., 1984). In contrast, McNeilly et al. (1986) hypothesized that the hypothalamo-pituitary axis of ram lambs selected for larger testes may be more sensitive to higher concentrations of gonadal steroids at an earlier age than lambs selected for smaller testes.

Boars with larger testes and boars with smaller testes may not have major differences in control of secretion of $\mathrm{LH}$ at the hypothalamo-pituitary axis. Instead, perhaps response of the testes to stimulation by LH is different between boars with larger testes and boars with smaller testes. Intact boars with larger testes had concentrations of $\mathrm{LH}$ similar to those of boars of the control group in the present study. Perhaps the testes of the boars with larger testes respond to $\mathrm{LH}$ by producing greater concentrations of testosterone than those of boars of the control group. We would have expected to detect differing concentrations of testosterone between the boars of the two groups if sensitivity of the testes to LH differed between boars from the two lines. Evaluation of testosterone after administration of a gonadotropin might change our interpretation of the results of the present study. Thus, a dose-response study is needed in which boars differing in testes size are given varying doses of $\mathbf{L H}$ and testicular production of steroids is measured.

In summary, boars with larger testes appear to have minor differences in secretion of $\mathrm{LH}$ from the anterior pituitary gland compared with boars from the control group. This was demonstrated by decreased amplitude of pulses of LH and suppressed response to administration of exogenous LHRH in the boars with larger testes.

\section{Literature Cited}

Carr, W. R. and R. B. Land. 1975. Plasma luteinizing hormone levels and testis diameter of ram lambs of different breeds. J. Reprod. Fertil. 42:325.

Colenbrander, B., Th.A.M. Kruip, S. J. Dielman and C.J.G. Wensing. 1977. Changes in serum LH concentrations during normal and abnormal sexual development in the pig. Biol. Reprod. 17:506.

D'Occhio, M. J., J. E. Kinder and B. D. Schanbacher. 1982. Patterns of LH secretion in castrated bulls (steers) during intravenous infusion of androgenic and estrogenic steroids: Pituitary response to exogenous lutcinizing hormone-releasing hormone. Biol. Reprod. 26: 249.

FlorCruz, S. V. and K. R. Lapwood. 1978. A longitudinal study of pubertal development in boars. Int. J. Androl. $1: 317$.

Gill, J. L. and H. D. Hafs. 1971. Analysis of repeated measurements of animals. J. Anim. Sci. 33:331.

Gill, J. L. 1986. Repeated measurcment: sensitive tests for experiments with few animals. J. Anim. Sci. 63:943.

Goodman, R. L. and F. J. Karsch. 1980. Pulsatile secretion of luteinizing hormone: differential suppression by ovarian steroids. Endocrinology 107:1286.

Hanrahan, J. P. and J. F. Quirke. 1977. Testis size and plasma luteinizing hormone as aids to sclection for fecundily in sheep. Anim. Prod. 24:148.

Harvey, W. R. 1979. Least-squares analysis of data with unequal subclass number. USDA-ARS H-4. U.S. Government Printing Office, Washington, DC.

Joakimsen, O. and R. L. Baker. 1977. Selection for litter size in mice. Acta Agric. Scand. 27:301.

Kelly, C. R. 1985. Characterization of follicle populations and gonadotropins during the estrous cycle in swine. M. S. Thesis. University of Nebraska, Lincoln.

Kiser, T. E., R. A. Milvae, H. D. Hafs, W. D. Oxender and T, M. Louis. 1978. Comparison of testosterone and androstenedione secretion in bulls given prostaglandin $\mathrm{F}_{2} \alpha$ or luteinizing hormone. J. Anim. Sci. 46:436.

Kittok, R. J., J. E. Kinder and R. K. Johnson. 1984a. 
Relationship between serum luteinizing hormone and estradiol in prepubertal boars. Theriogenology 21:303.

Kittok, R. J., J. E. Kinder and R. K. Johnson. 1984b. Effect of castration on plasma luteinizing hormone concentrations in prepubertal boars. J. Anim. Sci. 58:1271.

Land, R. B. 1973. The expression of female sex-limited characters in the male. Nature 241:208.

Mafizul Islam, A.B.M., W. G. Hill and R. B. Land. 1976. Ovulation rate of lines of mice selected for testis weight. Gent. Res. 27:23.

McNeilly, J. R., M. Fordyce, R. B. Land, G. J. Lee and R.
Webb. 1986. Endocrine differences in rams after genetic selection for testis size. J. Reprod. Fertil. 76: 131.

Niswender, G. D., L. E. Reichert, Jr. and D. R. Zimmerman. 1970. Radioimmunoassay of serum levels of LH throughout the estrous cycle of pigs. Endocrinology 87:576.

Schinckel, A. P., R. K. Johnson and R. J. Kittok. 1984. Testicular development and endocrine characteristics of boars selected for either high or low testis size. J. Anim. Sci. 58:675. 